バルビタール療法が奏効した重症破傷風 3 症例について

関西医科大学救命救急センター

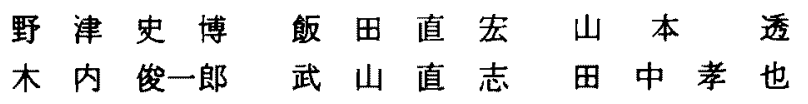

重症破傷風に対してバルビタール療法が奏効した 3 例を経験したので若千の考察を加 えて報告した。

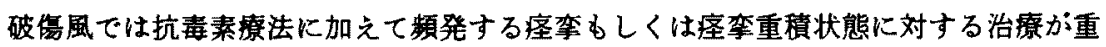
要となる. 3 症例にたいして疾挛抑制の目的にてサイフミラール $4 \mathrm{mg} / \mathrm{kg} / \mathrm{h}$ を維持量と して投与し，はぼ完全に㾏挛を㧕制しえた。本㞠法の留意点としては人工呼吸器が必要 なこと，喀痰の増加に伴 5肺合併症の出現，心不全，低血仕などであり，中止時期とし ては，1２ 週間，痓孪が完全に抑制された時期を選択すべきであり，必ず，2－3日， 投与量を漸减せしめたのち中止すべきである。

索引用語：重症破偤風, ハルビタール㞠法

はじめに

破傷風は重篤な全身㾏率, 呼吸困難および交感神释 の過緊張をきたす疾患であり，その管理には困難をき たす場合が多い，今回，私どもはハルビタール療法に て救命しえた重症破傢風 3 例について，本法の有用性 と経過中の合併应について報告する.

症例

症例 $1: 53$ 歳，女性。

主訴：全身性強直性痉䆛。

既往歴：特記すべきすのなし。

現病歴：転倒，㮩を挫創し近医にて䋖合処置を受け た. 受傷 5 日目, 開口障害が出現し入院, 創部の開放, 抗破傷風血清 (TIG)の処置を受けるも2時間後に後弓 反張が出現, 第 9 日目, 㾏孪重積状態となったため本 センターに搬送された。

現症：意識状態：200点(3-3-9度), 瞳孔不同なく樎 瞳, 全身硬直著明, 開口障害 ( 1 横指), 高血正, 頻脈 を諗めた。

入院時検奋所見：主たるるのとしては,白血球増加， GOT, GPT, LDH の上昇，特に CPK は3,250IU $/ l$ と 著明な上昇を示し, 血液ガスは強度の低酸素血症を呈 していた（表 1 ).

入院後経週：直ちに気管内括管下に人工呼吸を開始

昭和62年11月11日受付 63 年 3 月 1 日採用
するとともに，強直性㾏挛に対してサイアミラール4 $\mathrm{mg} / \mathrm{kg} / \mathrm{h}$ を維持量とし投与した（図 1). 以後, 疾挛発 作は完全に抑制され，第12病日以降，その量を漸減し 第19病日に中止した，抗毒素療法としてはTIG 総量 57,000IUを, 抗化学療法としてはセフェム系を中心と して投与した。なお，創部の細菌培善は陰性であった。 症例 $2: 37$ 歳, 男性.

主訴：開口障害，右下肢疼痛。

既往歷：䅺㽷病, アルコール性肝资。

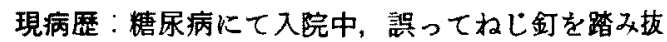
き右足を刺創す。10日後に開口障害, 右下肢の硬直が 出現し症状が増強したため本センターに搬送された。

現症: 意識清明, 縮瞳なし, 後弓反張, 全身疹挛は 認めなかったものの，㾏笑，開口障害（1横指）を認 めた。

入院後释過：入院時諸検亘は表 1 の如くである。入 院後より徐々に燕下困難, 項部強直, 後弓反張, 全身 㾏挛が出現し、それまで使用していたジゼバムでは 全く効果が認められなくなったため，第 3 病日，気管 内覒管下にバルビタール療法を開始した(図 2)。維持 量を $4 \mathrm{mg} / \mathrm{kg} / \mathrm{h}$ とし，時として起こる㾏挛発作にはシ アゼハム，ハンクロニウムにて対応した，第10病日， 心不全が出現したものの利尿都, カテコラミン使用に て軽快した，第11病日，右横隔神释麻疰が出現し第35 病日まで続いた(图了)。抗毒素虔法としてはTIG 総量 


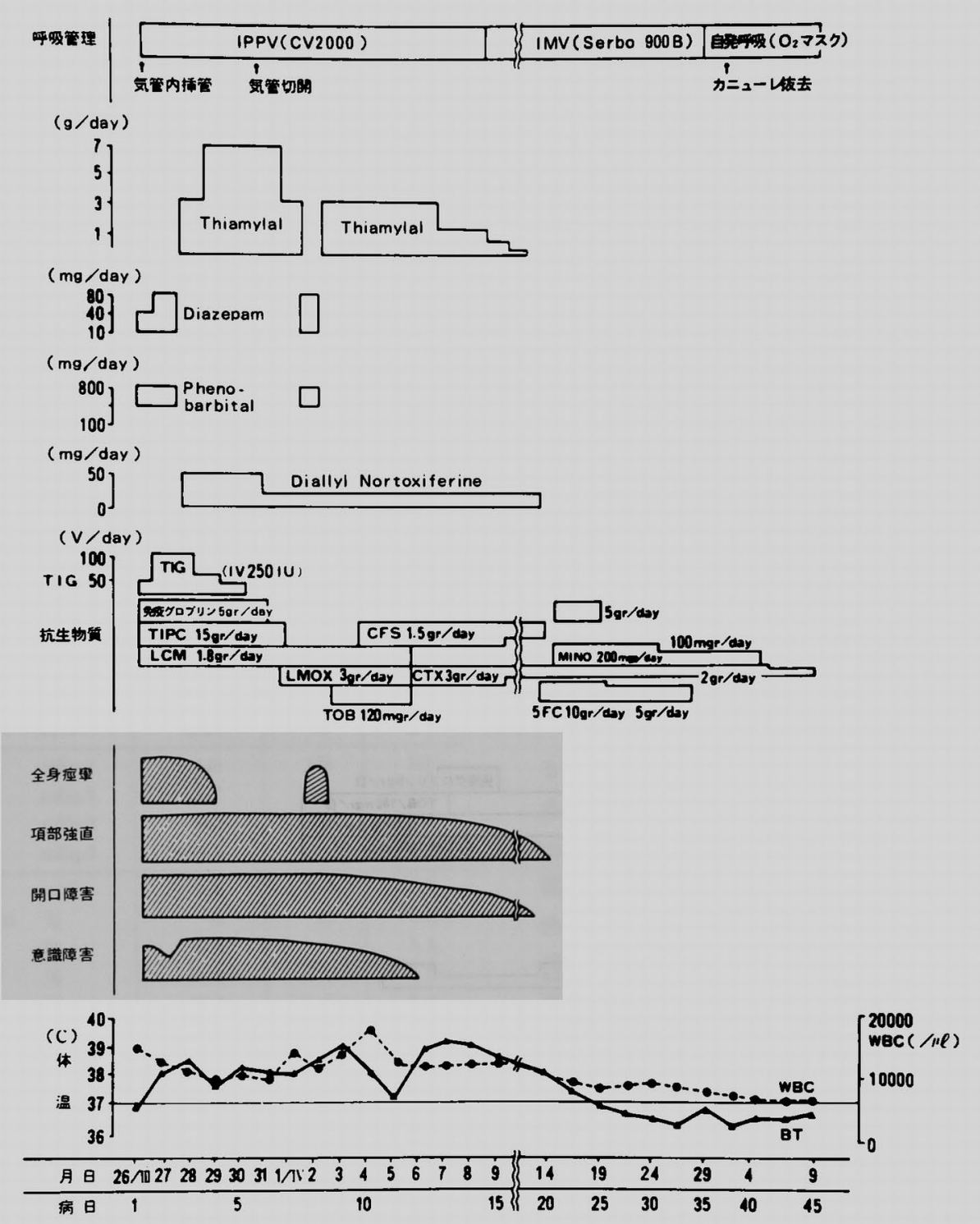

図 1 症例 1 の入院後経過

2265000IUを投与し，化学療法としてはセフェム系抗 生物質を中心として投与した。経過中，エンドトキシ ンか80pg と高値を呈し，DICを合併してきたため Gabexate mesilateなどにて対応した。なお，創部の 菌培養にて本菌が検出された。

症例：25歳, 男性.

主訴：項部痛, 開口障害.
既往歴：肺結核。

現病歴：自殺企図にて約 $3 \mathrm{~m}$ の高さより飛び降り後 頭部を挫創する。某医にて入院加療を受けていたが, 受傷 7 日目頃より, 項部硬直, 開口障害, 全身の硬直 性㾏挛が出現したため本センターに搬送された。

現症：意識清明, 縮瞳なし, 項部硬直強度, 開口障 害( 1 横指), 後弓反張, 全身疼挛は刺激により容易に 

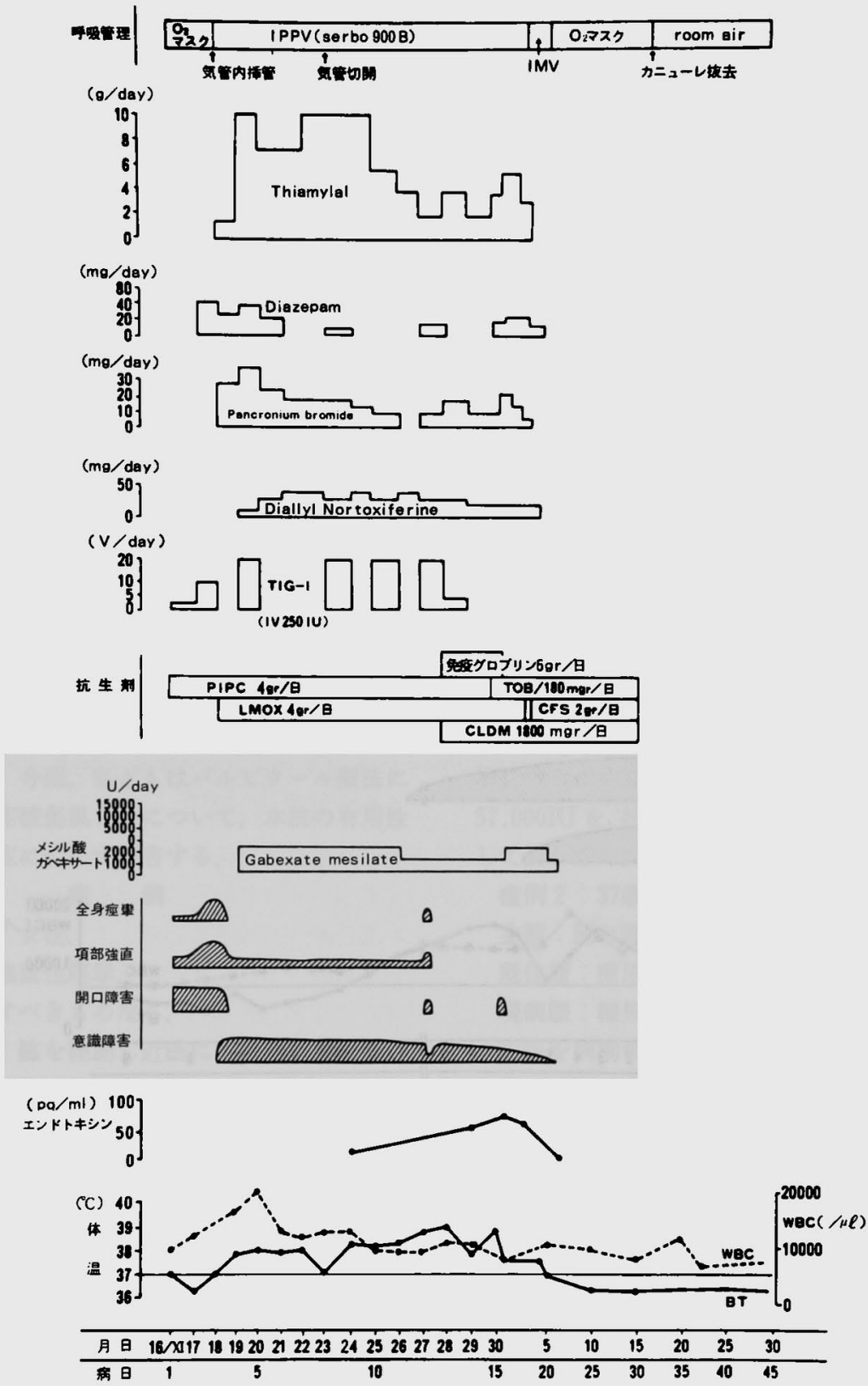

図 2 症例 2 の入院後経過 
表 1 症例 $1-3$ の入院時検査成績

\begin{tabular}{|c|c|c|c|c|c|}
\hline & & & 应例 1 & 症例 2 & 应例 3 \\
\hline \multirow{10}{*}{$\begin{array}{c}\text { 衣 } \\
\text { 梢 } \\
\text { 血 } \\
\text { 液 } \\
\text { 像 }\end{array}$} & $\mathrm{RBC}$ & $\times 10^{4} / \mathrm{mm}^{3}$ & 420 & 529 & 305 \\
\hline & $\mathrm{Hb}$ & $\mathrm{g}$ dl & 12.0 & 16.9 & 10.7 \\
\hline & $\mathrm{Ht}$ & ${ }_{0}^{\circ}$ & 36.3 & 47.8 & 33.6 \\
\hline & WBC & $/ \mathrm{mm}^{3}$ & 12600 & 10100 & 9200 \\
\hline & Band & $\%$ & 20.5 & 7.0 & 8.5 \\
\hline & Seg & $\%$ & 64.0 & 53.0 & 70.0 \\
\hline & Lym & $0_{0}^{\circ}$ & 12.0 & 31.0 & 31.5 \\
\hline & Plat & $\times 10^{4} / \mathrm{mm}^{3}$ & 15.6 & 25.1 & 16.2 \\
\hline & APT T & $\sec$ & 24 & 30 & 31 \\
\hline & PT & $\mathrm{sec}$ & 13 & 18.2 & 18.2 \\
\hline \multirow{12}{*}{$\begin{array}{l}\text { 血 } \\
\text { 液 } \\
\text { 生 } \\
\text { 化 } \\
\text { 学 }\end{array}$} & GOT & IU 1 & 266 & 33 & 83 \\
\hline & GPT & IU 1 & 92 & 23 & 40 \\
\hline & ALP & $1 \mathrm{U} / \mathrm{l}$ & 93 & 172 & 279 \\
\hline & TB & $\mathrm{mg} \mathrm{dl}$ & 0.6 & 0.9 & 2.0 \\
\hline & LDH & IU $/ \mathrm{I}$ & 1265 & 343 & 965 \\
\hline & BUN & $\mathrm{mg} / \mathrm{dl}$ & 14 & 10 & 10 \\
\hline & CRTN & $\mathrm{mg} / \mathrm{dl}$ & 0.7 & 0.9 & 0.9 \\
\hline & T.CHO & $\mathrm{mg} / \mathrm{dl}$ & 166 & 186 & 111 \\
\hline & $\mathrm{ChE}$ & IU $/ 1$ & 4293 & 6360 & 2960 \\
\hline & B.S. & $\mathrm{mg} / \mathrm{dl}$ & 140 & 156 & 90 \\
\hline & S-AMY & IU $\cdot 1$ & 50 & 87 & 133 \\
\hline & CPK & $\mathrm{IU} / \mathrm{l}$ & 3520 & 69 & 377 \\
\hline \multirow{4}{*}{$\begin{array}{c}\text { 霓 } \\
\text { 䍃 } \\
\end{array}$} & $\mathrm{Na}$ & $\mathrm{mEq} / 1$ & 140 & 138 & 141 \\
\hline & $\mathbf{K}$ & $\mathrm{mEq} / 1$ & 3.7 & 4.0 & 4.0 \\
\hline & $\mathrm{Cl}$ & $\mathrm{mEq} / 1$ & 102 & 105 & 104 \\
\hline & $\mathrm{Ca}$ & $\mathrm{mEq} / \mathrm{l}$ & 3.8 & 4.6 & 3.6 \\
\hline \multirow{6}{*}{$\begin{array}{l}\text { 蛋 } \\
\text { 白 } \\
\text { 分 } \\
\text { 画 }\end{array}$} & T.P & $\mathrm{g} / \mathrm{dl}$ & 5.8 & 7.5 & 7.9 \\
\hline & Albumin & $\%$ & 45 & 49 & 51.2 \\
\hline & $a_{1}$ & 0 & 5.5 & & 3.4 \\
\hline & $a_{2}$ & $\%$ & 10.8 & & 5.8 \\
\hline & $\beta$ & $\%$ & 11.8 & & 6.6 \\
\hline & $r$ & $\%$ & 26.6 & & 33.0 \\
\hline \multirow{3}{*}{ 䚪 } & 夜 王 & $\mathrm{mmH}_{2} \mathrm{O}$ & 230 & 160 & 150 \\
\hline & 蛋 白 & $\mathrm{mg} / \mathrm{dl}$ & 41 & 77 & 70 \\
\hline & 酸 & $\mathrm{mg} / \mathrm{dl}$ & 95 & 117 & 46 \\
\hline \multirow[t]{2}{*}{ 夜 } & 細胞数 & & $0 / 3$ & $0 / 3$ & 0.3 \\
\hline & 外 観 & & キ\#:トク口: & 無色 & 無色 \\
\hline
\end{tabular}

誘発された。深部反射は著明に六進していた。

入院後経過：入院時検查およびその経過は表 1, 図 4 の如くである. 第 1 病日よりバルビタール $4 \mathrm{mg} / \mathrm{kg} /$ $\mathrm{h}$ を目的量とし, その間, 時として起こる㾏挛にはジ ゼハムにて対応し, 疼挛は完全に抑制されていたため, 第12病日，ハルビタールを1.2mgに減量し，第14病日 に完全に中止したところ，再度痉辈が出現したため2 $\mathrm{mg}$ にて再開し第21病日まで続行した. その間, 軽度の 心不全をきたしたが利尿剩などにて軽快し，また，第 19病日には右無気肺を認めたが呼吸管理にて第25病日 には改善した．抗毒素療法はTIG 総量10,000IU を用 いた。なお，創部の細菌培養にて本菌が証明された。

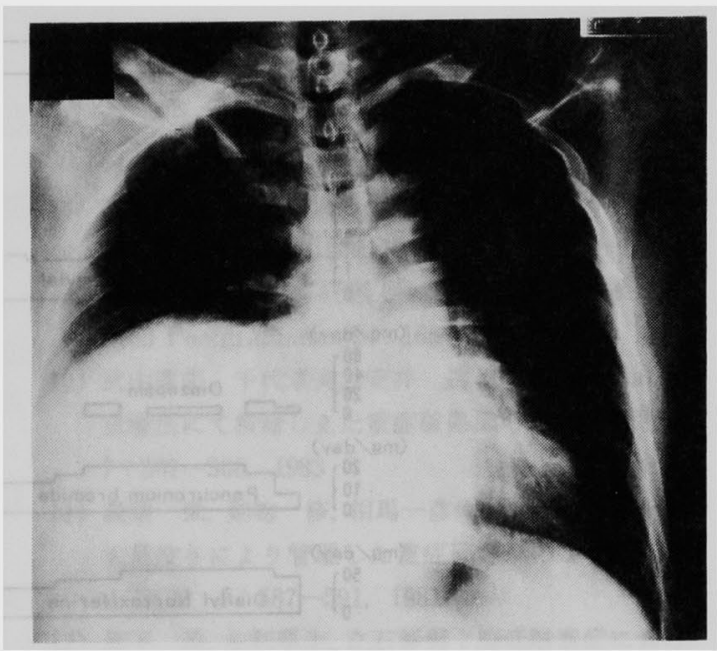

図 3 症例 2 で合併した右横隔神経麻疩所見

\section{考案}

破傷風菌はグラム陰性の嫌気性桿菌であり，産生す る菌体外毒素には tetanospasmin と tetanolysin とが あり"，前者が臨床症状発現に関与する. tetanospasmin は分子量150,000で血液やリンパ流により身体各 部に運ばれ神経笳接合部の神経終末膜に結合し, 上行 性軸索内輸送にて神経組織と接合する2)3)，破傷風に随 伴する交感神経の過度の緊張は毒素が交感神経節後線 維を上行しシナプスを越えて節前線維に達し，抑制線 維のブロックおよび視床下部の循環中枢の障害により 生ずるとされている214!. したがって，48時間以内に発 症する症例は致死量を越えた毒素が神経と結合するた め315)，死亡率は高くなり60\%にも達するといわれてい $3^{4) 6)}$. 私どもの症例では 3 例中 2 例に菌体を同定しえ たが，一般にはその同定率は28\%と低いため ${ }^{315)}$ ，初期 診断は臨床的見地から成されるべきである。

破傷風に対する治㞠は抗生物質と TIGにて成され ている. 抗生物質は破傷風毒素には無効であるが菌体 自体の殺菌と好気性菌の発育を阻止することによる破 傷風菌発育を抑制するといわれている7)8).TIG は神経 細胞に固着した毒素には無効であるが，流血中毒素， 新たに産生される毒素の中和には有効である7)9101. 従って破傷風の治療は自然解毒までの $2 \sim 4$ 週間にい かに患者の一般状態を管理するかが重要となる，中で も交感神経過緊張に伴う諸症状への対応が問題とな る. 従来のジアゼパム，筋弛緩㶡による治療では表面 的には㾏挛を抑制したとしても，真の交感神経過緊張 

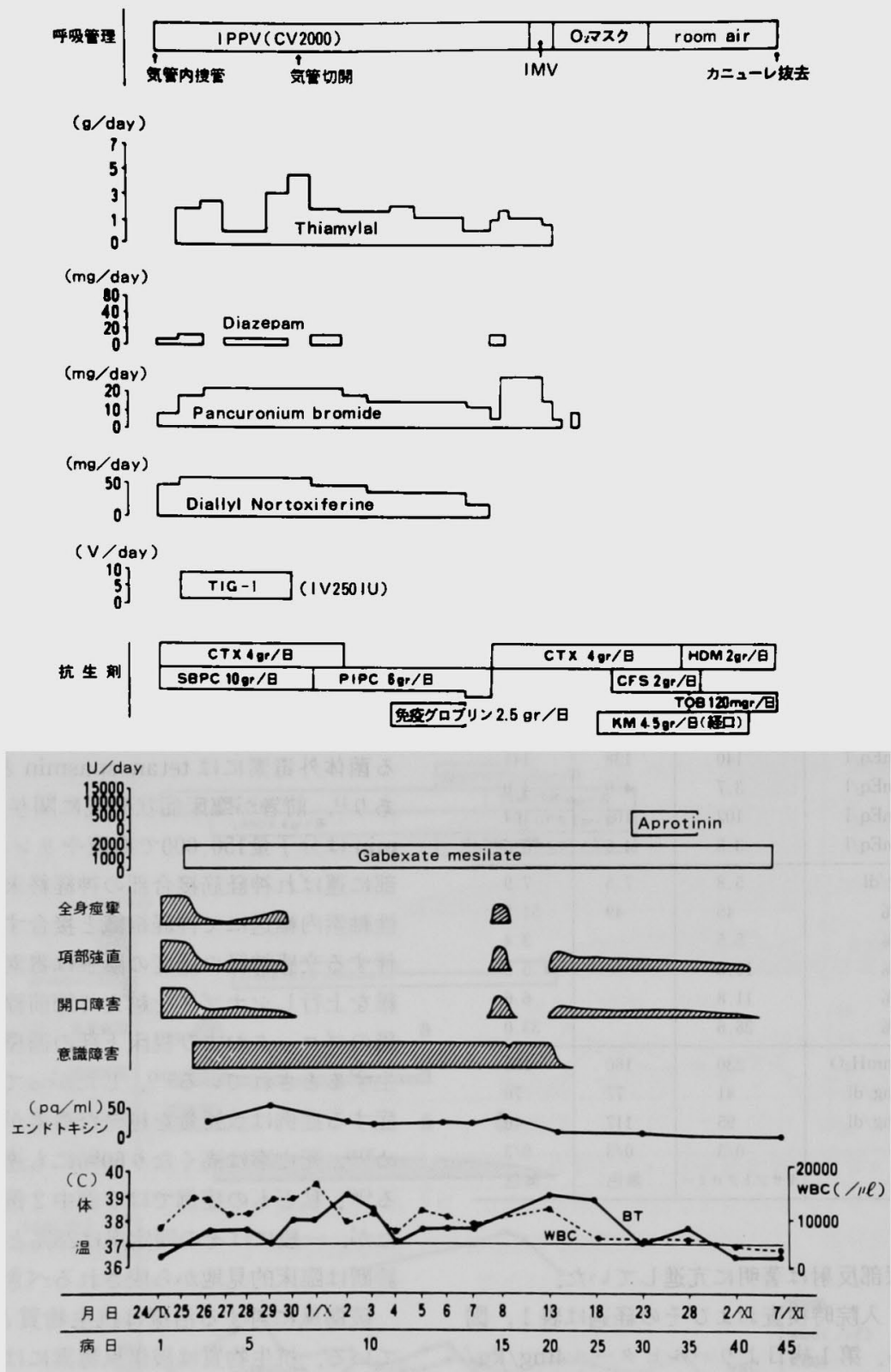

困 4 症例 3 の入院後経過

そのものは抑制しえない.そのためバルビタール療法 が推殞されている10111，バルビタールは副交感神経緊 張作用，脳保護作用，鎮疼作用などを有するため本症 の治療には最す合目的であるも ${ }^{912}{ }^{913}$, 本薬剤の使用に あたっては人工呼吸器を必要とし, しかも分泌物の増 加，咽頭筋麻疸，心抑制，血管運動神経抑制などの副 作用を有するため細心の注意が必要となる、私どもの
症例でも分必物增加に伴う無気肺，心不全，低血王， 気管支㾏挛などを認めた。なお症例 2 では横隔神経麻 㾝を認めたが、このような報告は未だ無く，わずかに 剖検例の報告(1)11)にて横隔膜に中等度の壊死, 变性を 認めたとあるのみであり，その原因は定かでないすの の, 何らかのかたちで本毒素が神経障害発症に関与し たものではないかと思われた。 


$$
\text { おかりに }
$$

重症破傷風の㾏尜重積状態の抑制を目的として心ル ビタール療法を施行し，著效を示した 3 症例について， その有効性と本療法に伴う合併症について若干の考察 を加えて報告した。

\section{文献}

1）井口, 池田俊彦、安部敬雄：破伤風、外科治療 $25: 334-340,1971$

2) Kerr J : Current topics in tetanus. Inten Care Med 5: 105-110, 1979

3) Kryzhanovsky GN : Tetanus, a polysystemic disease. Proceedings of the fourth intemational conference of tetanus. 189, 1975.

4) La Force FM, Young LS, Bennett JV: Tetanus in the united states (1965-1966). Epidemiologic and clinical features. New Eng J Med 280: 569-577, 1969

5）松田守弘：Tetanus Toxin, 生体の科学 $35: 443$ $-445,1984$

6）海老沢 功，本間れい子：破伤風の子後に影锌を
与える因子について，感染症誌 $60: 125-132$, 1986

7）大熊隆介：破傷風の猃断上の再認識。臨と研 57 ： $64-68,1975$

8）本間れい子：破傷風治療における問題点，救急医 $10: 1603-1616,1986$

9）金谷透：良好に趶過した破侮風の1治鈋例， Med Postgraduates $24: 165-170,1986$

10）武山直志，千代军夫，安井透他：Thiamylal 大 量療法にて数命しえた重应破偤風の 1 例，救急医 $7: 501-506,1983$

11）高梨 栄, 剣物 修，相馬一彦他：チオベンタール 大量投与により管理した重症破伤風の 1 例，ICU と CCU 5:587-591，1981

12）武下浩, 左利厚生, 立石彰男：脳低酸素症におけ る barbiturateの脑保謢作用，医のあゆみ 107 ： $359-368,1978$

13）次田祐介，阪本敏久，定光大海他：重症頭部外偤に 奶する barbiturates 療法. 頭蓋内王亢進症に対す る mild barbiturate therapy，救急医 $7: 619$ 625,1983

\title{
EFFECT OF BARBITAL THERAPY IN THREE CASES OF SEVERE TETANUS
}

\author{
Humihiro NOZU, Naohiro IIDA, Tohru YAMAMOTO, Shunichiro KIUCHI, \\ Naoshi TAKEYAMA and Takaya TANAKA \\ Emergency Care Unit, Kansai Medical University
}

Three patients with severe tetanus were successfully treated by barbital therapy.

In the management of tetanus it is important to provide treatment for frequently occurring convulsion or an accumulated convulsive status in addition to antitoxin therapy. The present three patients with severe tetanus showed almost complete suppression of convulsion by administration of thiamylal at a maintenance dose of 4 $\mathrm{mg} / \mathrm{kg} / \mathrm{h}$. It is necessary, however, to take into account the necessity of using an artificial ventilator, possible occurrence of pulmonary complications accompanied by increased sputum production, heart failure and hypotension. Medication should be discontinued after the dose has been gradually decreased for $2-3$ days, when the convulsion has been completely suppressed for $1-2$ weeks after initiation of the therapy. 